\title{
Television as an Instructional Tool for Concept Analysis
}

\author{
Nnenna Ngozi Benwari ${ }^{1, *}$ \\ ${ }^{1}$ Department of Teacher Education, Faculty of Education, Niger Delta University, Bayelsa State, Nigeria \\ *Correspondence: Department of Teacher Education, Faculty of Education, Niger Delta University, Bayelsa State, \\ Nigeria. E-mail: nenabenwari@yahoo.com
}

Received: November 19, 2014

Accepted: January 24, 2015 Online Published: February 5, 2015

doi:10.5430/wje.v5n1p124

URL: http://dx.doi.org/10.5430/wje.v5n1p124

\begin{abstract}
This is a study of the perception of teachers on the use of television for concept analysis in the classroom. The population of the study is all the 9,784 Secondary School teachers in Bayelsa State of Nigeria out of which 110 teachers were randomly selected using the proportional sampling method. The instrument is a questionnaire designed by the researcher but validated by experts in test and evaluation and tested for reliability using the Pearson Product Moment Correlation Coefficient. It was established at 0.87 which shows that the instrument is reliable. One hypothesis was designed for the study and the data was analyzed using the Mann-Whitney U-test statistical analysis. The findings of the study reveals that there is no significant difference in the perceptions of male and female secondary school teachers on the use of television as an instructional tool for concept analysis in the Secondary Schools. It was therefore recommended that the use of television should be an accepted innovation and should be encouraged to broaden and encourage learning activities in schools.
\end{abstract}

Keywords: television; attitude; perception; ICT; ITV

\section{Introduction}

Many developing nations are witnessing a tremendous increase in the number of school age children in the last ten years according to a United Nations report. This phenomenon has led to population explosion leading to an increase in enrolment. Thus, the educational system in most of those nations is stretched beyond the limit most schools can accommodate. Many classrooms also lack teachers in some subject areas in spite of the increase in the number of children enrolling in the schools. These nations including Nigeria are looking for alternative teaching strategies closely related to havinga live teacher. Instructional Television (ITV) is one of these.However; it is common knowledge that for any alternative teaching/learning to be effective, that strategy must be acceptable to both teachers and students in the school.

In the mid 1980's, the television entered into its fourth decade as a mass medium and blossomed from a remote, expensive, restricted business to what some referred to as of abundance. Television is now easily accessible for use in education not only over-the-air broadcast but also by means of video recorder, closed circuit, cables and systems, all of which may be linked by satellite relays.

Vast libraries of programmes are now available as audio discs, Video Compact Discs (VCDs), Digital Video Displays (DVDs). Portable recorders enable instructors and their students to create their own materials from the television programmes. With this development, the television now represents a rich resource for instruction and training rather than being used only for commercial or entertainment purposes.

This has led to the birth of the term instructional television (ITV). ITV refers to planned use of video programmes to meet specific instructional goals regardless of the programs or setting in which they are used. This includes commercial broadcast, business and industry training. Television also, is now an item that can be found in every household and it is becoming increasingly affordable. The average family even in the rural communitieshas a Television set and a Video player with which they watch home videos. This holds true in such communitieswhere more recent technologies like the computer are not easily available, television holds the promise of enhancing teaching and learning. 


\section{The Problem}

The quest to improve the quality of teaching and learning has led to the application of various techniques and technologies in teaching.Educationists have continued to apply more recent technology in the classroom to enhance students' performance. However the availability and usability of such in the particular environment, especially in the developing countries, is an issue of concern. However the television which shows great promise of filling this gap in such environments has been grossly neglected.The teachers do not employ it for instructional purposes even though the resources are available. This has led to this study on the use of television as an instructional tool for concept analysis.

\section{Literature}

The television is a technology that was developed primarily for entertainment and commerce. However, in the early 1950's, instructional television (ITV) began to evolve. It was expected to replace the traditional classroom teacher and thereby increase the quality of teaching. This has not been the case as ITV is rather enhancing the role of the teacher (Hendry 2001). Studies by Baridam (2000) and Levis (2003) have also shown that teachers generally have a favourable disposition towards the role of other media for instruction rather than the television. According to Ikot (2004),

\section{Presentation media have been the teachers' mainstay until now. In typical face-to-face teaching situation, the teacher is the sole receiver, stopper, and interpreter of anything the student may say or do.}

The impact of television on society has led some people to refer to it as a source of socialization that tends to compete with the acknowledged agents of socialization such as family, the school, the peer group, the church among others in providing influential models that may be emulated. It has been argued that the role of television as a medium is so great that children and adolescents in particular, change their attitude about people and activities to reflect those encountered in television programmes.

Even though some people see television programmes as an effective teaching resource, others assert that it is a dangerous corrupter of nations' morals, yet the more radical critics claim that it is at best, a waste of the viewer's time.

The television as a media for transmitting instruction is subject to the following limitations:

i. Lesson time is not flexible in the case of the broadcasted form from television stations and so sometimes inconvenient.

ii. The class teacher has no control over the pace of development of a television lesson.

iii. It is difficult to take account of the variations in attainment and ability within an age group.

iv. Intimations and distractions at the receiving end can seriously impair the effectiveness of a lesson.

v. The effectiveness of any transmitted material is limited to the range of the transmitter.

Another critic, Dale (2010) frowned at the use of the television as an instructional material. As a one-time school headmaster, he maintained that through the television young minds are bombarded from the earliest infancy onward with high potency stimuli and so intellectual organization becomes low. He discards any belief that children learn anything from the television. Rather, he believes that the television makes for various experiences but does not make for any critical or conceptual framework by which to understand this experience. Balogun, (2009) described the television as an instructional tool, which has a one-way channel of communication. This implies that the instructional television has little or no feedback from the target audiences.

Arnove, (2003) citing research on ETV utilization sampled the opinion of the user teachers during the INSAT programme in India. The response of the teachers did bring out certain factors which were impeding fuller utilization of ETV programmes. These are summarized as follows:

i. Among the teachers who were not able to watch all the ETV programmes, 62 percent mentioned malfunctioning of their television(TV) sets while 40 percent of the teachers further reported that though their sets functioned, either the quality of the pictures or the quality of the sound was not clear probably due to long usage.Teachers reported that TV repairs was not undertaken on time despite repeated request to the programme facilitator. 
ii. Another major reason for less than full utilization of ETV programmes was the failure of electricity, which was a common problem in the area.

iii. Lack of awareness about the telecast due to non-availability of teachers, notes and programmes schedule in a majority of cases and their late receipt in the some cases.

iv. Non-payment of remuneration to the TV custodians, which was once promised to them, discouraged them from being committed.

Also a research programme carried out on teachers attitude during the SITE programme in India pointed out that the teachers' responses revealed the hold of traditional teaching method and values, poverty of knowledge of content, inability to think, to reason and express, a cultural lack which makes the teacher insensitive to the new medium and almost incapable of responding to it. Also, impact was assessed on the basis of their rating on utility of programmes for teaching purposes, free comments on programmes and ideas on post-telecast or follow-up activities that the programme suggested to them and it was discovered that 69 percent to 87 percent of teacher loved the ETV programmes.

However, from the suggestions in the free comments on ideas and follow-up activities showed that most of the teachers were in a very autocratic way of dominance over the children. It needed considerable change in teachers' attitude towards teaching learning situation.

In a similar experiment, it was observed that teachers preferred syllabus based programmes. The average percentage given by the teachers or syllabus based programmes was 64.58 percent and for enrichment programmes, it was 35.42 percent. The Teachers reaction toward regional language programmes were as follow:

i. Language should be simple, easy and according to the level of the children.

ii. English words should not be used.

iii. Correct expression and pronunciation should be used.

On the aspect of style and presentation eleven teachers had shown preference for dramatized form, seven for films, three for poems and riddles and two for use of games in the programmes. All teachers expressed the view that the lecture format was not liked by children. All teachers were of the opinion of having notes for every programmes, so that the pre and post-telecast activities could be properly conducted.

It was also observed that most of the teachers from these schools accepted the TV as a welcome help as they expressed agreement with the positive statements such as 'teacher too learn about better methods of teaching and subject matter', given to same amount of time, students learn more from the TV. They have disagreed with negative statements pertaining to these programmesviz, 'because of TV lessons, students do not pay attention to the classroom teachers' and 'TV wastes my teaching time'.

The research findings advised in view of the inadequate facilities available in the schools and wider acceptance of $\mathrm{TV}$ as an aid on the part of the teachers, field of its operation maybe widened and its use encouraged.

On the other hand, some factors were favourable to the use of ETV programme. These were;

i. Time slot for telecast of ETV programmes from 10:30am to 11:15am was favoured by the teachers.

ii. The teachers liked the arrangement of putting the programmes to younger children first.

iii. Regarding quality of the ETV programmes the teachers had generally, favourable attitude, particularly those produced by the CET.

iv. However, some of the teachers felt that the content of some specific programmes series was a bit above the level of the intended audiences, the language used was somewhat difficult to understand) the speed of presentation not appropriate, and the presentation not very interesting.

However Ahwotua-Efebo and Nemine (2005) have allayed the fears of teachers who see the television as a threat to their job explaining that the television is not a teacher replacement but a multi-media, audiovisual resource for the teacher's use, and the viewing should be a shared experience so that the teachers can gauge the children's response.

Other critics buttress their argument by pointing out and advancing the reason that it encourages passivity on the part of the viewer especially for instructional purposes. In Bishop, (2006) one critic went on to say that the television renders a teacher lazy because the better structured a television lesson is, the less teaching and instruction on topic the teacher does. 
Despite the limitations of the television, and the negative attitudes towards it use for instruction, it still has one of the greatest potentials as an audiovisual resource in the field of education. It is consequently relieved upon, and statement of problem.

The television enhances sight and sound and can be used to clarify abstract concepts which might be difficult to explain. One way of applying ITV may be to present short clips on a topic before presenting the abstract concepts thus making ITV a buffer teaching tool for the teacher.

\section{Purpose of the Study}

The purpose of the study therefore is to find out if there is any significant difference in the perceptions of male and female teachers on the use of television as an instructional tool for the teaching of certain basic abstract concepts in the secondary school.

The study intends to find out whether itwould offset the shortfalls in the quality and quantity of teachers. Norman (2011) has opined that the TV as a media is without doubtone of the most powerful communication forces ever created by man.

Thus instructional television is expected to boost education but in Nigeria its impact is still relatively low as compared to other developing countries. It may even be misinterpreted and resisted by some in the educational set up. This research work has therefore been designed to find out the attitude that maylead to the rapid development or impair the use of the instructional television in enhancing the teaching learning process and affect educational development generally.

\section{Hypotheses}

$\mathrm{H}_{0}$ : There is no significant agreement in attitude among male and female secondary school teachers towards the use of instructional television in concept analysis during classroom instruction.

$\mathrm{H}_{1}$ : There is a significant agreement in attitude among secondary school teachers towards the use of instructional television in concept analysis during classroom instruction.

\section{Method}

This is a descriptive survey. One hypothesis was formulated simply to find out if there is a significant difference in the perceptions of male and female teachers towards the use of television for concept analysis in the process of teaching. 110 teachers were randomly selected from the 9,784 teachers in Bayelsa State of Nigeria. The questionnaire consists of two sections. Section A sought demographic data of the respondents while section B is concerned with the perceptions of teachers concerning the use of television for concept analysis in instruction. 104 out of 110 questionnaires were returned.

\section{Data Analysis Technique}

In this work the statistical tool used in the analysis of the data collected is the Mann-Whitney U-test. This was adopted based on the questionnaire design and the fact that the questions of the testing of hypothesis were based on ordinal scale.

Mann-Whitney U-Test

$$
\mathrm{U}=\mathrm{n}_{1} \mathrm{n}_{2}+\underline{\mathrm{n}}_{1}\left(\mathrm{n}_{1}+\frac{1}{2}-\mathrm{R}\right.
$$

Or

$$
\mathrm{U}=\mathrm{n}_{1} \mathrm{n}_{2}+\underline{\mathrm{n}_{1}} \underline{\left(\mathrm{n}_{2}+1\right)}
$$

Where $\mathrm{R}_{1}=$ the sum of ranks assigned to sample with size $\mathrm{n}_{1}$

$\mathrm{R}_{2}=$ the sum of ranks assigned to sample with size $\mathrm{n}_{2}$

The volumes for $u$ can be obtained by using the above two formulas 


\section{Result}

Table 1. Analysis of Response Rate

\begin{tabular}{llll}
\hline No. of Schools & No. Questionnaires sent out & No. Returned & Response Rate (Percentage) \\
\hline 11 & 110 & 104 & $95 \%$ \\
\hline
\end{tabular}

Table 2. Response Pattern Showing Attitude of Teachers to ITV

\begin{tabular}{|c|c|c|c|c|}
\hline \multirow[t]{2}{*}{$\mathrm{S} / \mathrm{N}$} & \multirow[t]{2}{*}{ Teachers } & \multirow[t]{2}{*}{ No. of Occasions in use } & \multicolumn{2}{|c|}{ Response in Attitude } \\
\hline & & & Rank agreed & Rank disagreed \\
\hline 1 & 1 & 1 & & \\
\hline 2 & 2 & 1 & & \\
\hline 3 & 3 & 2 & 4 & \\
\hline 4 & 4 & 2 & 4 & \\
\hline 5 & 5 & 2 & 4 & \\
\hline 6 & 6 & 3 & & 7 \\
\hline 7 & 7 & 3 & 7 & \\
\hline 8 & 8 & 3 & 7 & \\
\hline 9 & 9 & 4 & & 9.5 \\
\hline 10 & 10 & 4 & & 9.5 \\
\hline 11 & 11 & 5 & & 11 \\
\hline 12 & 12 & 6 & 12.5 & \\
\hline 13 & 13 & 6 & 12.5 & \\
\hline 14 & 14 & 7 & 14.5 & \\
\hline 15 & 15 & 7 & 14.5 & \\
\hline 16 & 16 & 8 & 16 & \\
\hline 17 & 17 & 9 & 17 & \\
\hline 18 & 18 & 10 & & 18.5 \\
\hline 19 & 19 & 10 & & 18.5 \\
\hline \multirow[t]{2}{*}{20} & 20 & 12 & & 20 \\
\hline & & & $\sum \mathrm{R}_{1}=113$ & $\sum \mathrm{R}_{2}=97$ \\
\hline
\end{tabular}

Teachers attitude which agree with instructional television, the sum of the rank, $R_{1}$ is 113 and the sum of the rank of teachers which disagree with instructional television $R_{2}$, is 97 .

Therefore, the U statistical can now be computed, thus:

$$
\begin{aligned}
& \mathrm{U}=\mathrm{n}_{1} \mathrm{n}_{2}+\underline{\mathrm{n}_{1}}\left(\frac{\left.\mathrm{n}_{1}+1\right)}{2}-\mathrm{R}_{1}\right. \\
& \text { Or } \\
& \mathrm{U}=\mathrm{n}_{1} \mathrm{n}_{2}+\underline{\mathrm{n}_{2}} \underline{\left.\underline{\mathrm{n}_{1}}+1\right)}-\mathrm{R}_{2}
\end{aligned}
$$

Where $\mathrm{R}_{1}=$ the sum of ranks assigned to the sample with size $\mathrm{n}_{1}$

$\mathrm{R}_{2}=$ the sum of ranks assigned to the sample with size $\mathrm{n}_{2}$

The volumes for $\mathrm{U}$ can be obtained by using the above two formulas

$1^{\text {st }}$ Formula $\mathrm{U}=11(9)+\underline{11(11+1)}-113$

$\mathrm{U}=11(9)+11 \times 6-113$ 
$\mathrm{U}=99+66-113=\mathrm{U}=52$

$2^{\text {nd }}$ Formula $U=11(9)+\frac{9(9+1)}{2}-97$

$\mathrm{U}=11(9)+9 \times 5-97$

$\mathrm{U}=99+45-97$

$\mathrm{U}=4.7$

In testing the null hypothesis we use 4.7 which is the lesser of the two computed values.

Decision Rule:

If the computed $U$ value of 4.7 is equal to or less than the tabulated $U$ value accept null hypothesis otherwise reject null hypothesis.

With a significant level of 0.5 , using a critical $U$ values having $n_{1}=11$ and corresponding to $n_{2}=9, U$ is 23 .

Since the smaller $U$ (4.7) is higher than the critical U (23), we therefore reject null hypothesis and accept alternate hypothesis that there is a significant difference in attitude among secondary school teachers towards the use of instructional television in concept analysis during classroom instruction.

\section{Discussion}

The study is based on the assumption that an assessment of teachers attitude towards the use of the television as a medium of instruction would eventually provide great assistance in highlighting factors impeding its use so as to enable media technologists to develop a more suitable format for use.

The study is also designed to investigate factors responsible or factors that must have formed a negative or positive attitude in teachers in post primary schools on the use of ITV.

Thus the discussion is based on the findings predicated on the hypothesis that there is a significant difference in teachers' attitude whether negative or positive towards the use of the instructional television. It is evident from teachers' response that they are not neutral or passive towards the use of ITV. They have a favourable disposition towards its use. This means they have a positive attitude towards the instructional television. From the items in the questionnaire, they identified the use of television as instructional and motivational, time saving and also stimulate discussion class etc. It also revealed that they preferred to use the video recorder as against other devices of ITV. This implies that they want ITV equipment that will suit formal school time i.e. presented within their school. Their responses also show that education programmes broadcasted from television stations were general, too fast in presentation and could not serve meaningful instructional purposes.

\section{Recommendations}

The study has clearly portrayed teachers recognition of the potential of the television for instructional purposes and their readiness to use it by their positive attitude toward its use and so the following recommendation are positive attitude toward its use and so the following recommendations are made:

i) According to Davis (2010) the "Television is a new and sophisticated technology. To prove useful, it has to be properly integrated within the educational system, which is old, traditional, closed, well guarded and very slow to accept innovations. It is with worth mentioning that in spite of the above comment, the television has gained great acceptance and therefore the government and other well meaning bodies should provide necessary fund and adequate facilities to see to its proper utilization in secondary schools.

ii) There should be more emphasis on the use of ITV in schools both at the primary and post primary levels. So that students will be familiar with its use before they get to the secondary schools.

iii) Television stations should be made to broadcast well planned and designed instructional lessons suitable to the learners' level of education and their local environment in designing lessons i.e. common examples from every-day life.

iv) Teachers should be given pre-transmission so as to enable them prepare learners before broadcast.

v) Educational programmes should be aired the afternoons so as to be useful during formal time.

vi) Speed of presentation and language use should be designed to suit learners. 
vii) Videocassettes on different topics from different subject areas should be properly designed for school use.

viii) Each school, should have resource centres with necessary gadgets were every classroom teacher can go and prepare video lesson etc. for individual class use i.e. CCTV (closed circuit television within a school).

ix) Bayelsa State government should make it a primary concern to have special television studio, were they can air instructions on different subjects on television for students to benefit at home as was obtainable in the then, rivers-State in the late 80 's.

x) In service courses, seminars, workshops etc are organized on regular basis for all categories of teachers to keep them abreast with new innovations in education specially pertaining to instructional design.

xi) Regular needs analysis and evaluation should be carried out to remove obsolete instructional television programmes and replaced by new ones introduced by Professionals in such areas.

xii) Educational technologist and technicians should be stationed in schools so as to maintain facilities.

\section{Conclusion}

The following conclusions are made on findings and discussion of the study:

i) Since teachers have a positive attitude towards the use of the instructional television (ITV) it shows that if there are adequate facilities and the quality of programmes improved, the medium would be utilized more effectively.

ii) Good operative educational materials and equipment that will achieve the aim and objectives of the use of ITV be sent to schools. In-services courses, seminars and workshops, updating the skills and knowledge on the use, and many advantages of the ITV and report funding should be carried out by the government, philanthropist, oil companies, well meaning bodies such as Parents' Teachers' Association (PTA), stakeholders etc.

\section{References}

Arnove, R. F. (2003). Educational Television - A Policy Critique and Guidefor Developing Countries. New York: Praeger Publisher.

Awotua-Efebo, E., \& Nemine E. B. (2005). Video Cassette as an Effective Instructional Strategy for Students. Journal of Educational Review (JOER), 1(4), 18-21.

Balogun, D.A. (2009). The Use of Audio-Visual Materials in Geography Teaching in post Primary Schools in Nigeria. West African Journal of Education, 8(3), 14-18.

Baridam, D.M. (2000). Research Method in Administrative Studies. Port Harcourt: Paragraphic Publishers.

Bishop, G. (2006). Innovation in Education. London: Macmillan.

Dale, E. (2010). Audiovisual Methods in Teaching. NewYork: Free Press.

Davis, K. (2010). Human Behaviour at Work: A Study in Organizational Behaviour (5 ${ }^{\text {th }}$ edition). Columbia: University Press.

Hendry, D. (2001). Instructional television's changing role. The technology source. Retrieved from http://ts.mivu.org/default.asp?show=articles\&id=1034

Ikot, Andriessen. (2004). Application of Audiovisual Techniques in Aspect of Educational Technology in the year 2000. Uyo: Business Press.

Levis, E. A Study to Determine Teachers Receptions in Relation of Educational Media, Standford Eric Research Abstract for AECT Conception Publisher USA.

Norman, S.S. (2011). New Media in Higher Education and Department of Audiovisual Instruction N.E.A. Washington D.C. 